9 Holgate ST, Noonan M, Chanez P, et al. Efficacy and safety of etanercept in moderate-to-severe asthma: a randomised, controlled trial. Eur Respir J 2011; 37: 1352-1359.

10 Dooley MA, Jayne D, Ginzler EM, et al. Mycophenolate versus azathioprine as maintenance therapy for lupus nephritis. N Engl J Med 2011; 365: 1886-1895.

\title{
Occupational asthma from sensitisation to 4,4-methylene-bismorpholine in clean metalworking fluid
}

\begin{abstract}
To the Editor:
European Respiratory Society guidelines on the management of work-related asthma recommend that occupational asthma with an allergic mechanism should be diagnosed by both identifying the workplace as the cause, and confirming sensitisation to the asthmagen by specific inhalational challenge (SIC), in the absence of any available specific IgE tests $[1,2]$. Used (contaminated) metalworking fluid is the usual cause of occupational asthma in exposed workers. We present the first case of occupational asthma due to the biocide additive 4,4-methylene-bismorpholine present in clean metalworking fluid.
\end{abstract}

A 54-year-old Kenyan male presented with a 2-year history of rhinitis, wheeze, dry cough and chest tightness, which were worse at night and while at work, and improved away from work on holiday. He had had rhinitis from grass pollen, perfumes and cleaning agents intermittently for 15 years, and acne due to metalworking fluid 5 years previously. There was no childhood or family history of asthma and he had never smoked cigarettes. He had been employed as a machine tool setter operator for 22 years manufacturing car axles. For the past 6 years he had worked on an enclosed computer numerical controlled milling, drilling and boring machine, with its own oil sump, using carbide-tipped tools. It was loaded by a robot but there was no delay between the end of machining and door opening, which produced a visible mist about $3 \mathrm{~m}$ from his work station. The machines used Fuchs Ecocool Ultralife A, a semi-synthetic metalworking fluid for aluminium alloys. Clinical examination and chest radiograph were unremarkable. Skin-prick allergy testing (SPT) revealed a $0 \mathrm{~mm}$ reaction to $0.9 \%$ saline and a $7 \mathrm{~mm}$ reaction to histamine hydrochloride $10 \mathrm{mg} \cdot \mathrm{mL}^{-1}$. There were positive reactions to grass pollen $(8 \mathrm{~mm}), \operatorname{dog} \operatorname{dander}(5 \mathrm{~mm})$, cladosporium $(4 \mathrm{~mm})$ and 4,4-methylene-bis-morpholine $(3 \mathrm{~mm})$, with borderline reactions to $5 \mathrm{mg} \cdot \mathrm{mL}^{-1}$ cobalt chloride $(2.5 \mathrm{~mm})$ and clean metalworking fluid $(2.5 \mathrm{~mm})$. Total IgE was $2048 \mathrm{kU} \cdot \mathrm{L}^{-1}$, white blood cell count $7.81 \times 10^{9} \mathrm{~L}^{-1}$ and eosinophil count was raised at $0.75 \times 10^{9} \mathrm{~L}^{-1}$. Two-hourly peak flow measurements made at home and work over 4 weeks were analysed using OASYS [3, 4]. The OASYS score was 3.4 and the area between the curves score was $23.4 \mathrm{~L} \cdot \mathrm{min}^{-1} \cdot \mathrm{h}^{-1}$ confirming a significant work effect (fig. 1a). Spirometry revealed a borderline obstructive ventilatory defect (forced expiratory volume in $1 \mathrm{~s}$ (FEV1) to forced vital capacity (FVC) ratio 70\%) with normal indices (FEV1 $2.75 \mathrm{~L}, 86 \%$ predicted; FVC $3.95 \mathrm{~L}, 100 \%$ predicted). While work-exposed, his fractional exhaled nitric oxide (FeNO) was raised at $71 \mathrm{ppb}[5,6]$ and nonspecific bronchial responsiveness (NSBR) to methacholine was normal ( $>4800 \mu \mathrm{g}$ by the Yan method [7]).

He underwent SIC after 3 weeks away from work. He was challenged with 7\% clean Ecocool Ultralife A metalworking fluid in water for a total of $50 \mathrm{~min}$ via a Turboneb II (Clement Clarke International Ltd, Harlow, UK) and Maxineb (Flexicare Medical Ltd, Mountain Ash, UK) nebuliser. Initial FEV1 was 2.63 L, which fell immediately by $20 \%$, recovering after $15 \mathrm{~min}$, and fell again at $3-11 \mathrm{~h}$ by $29.7 \%$, accompanied by asthmatic symptoms. Subsequent SIC to $0.7 \%$ 4,4-methylene-bismorpholine in water (Chemical Abstract Service (CAS) registry number 5625-90-1; occupational asthma hazard index 0.98) for a total of $50 \mathrm{~min}$ resulted in immediate sustained rhinitis symptoms, then a late fall in FEV1 of $16.5 \%$ from $2.36 \mathrm{~L}$, at 9-11 h after challenge (fig. 1b). He had a more than four-fold increase in NSBR to methacholine (pre-SIC cumulative dose that caused a $20 \%$ fall in FEV1 (PD20) $>4800 \mu \mathrm{g}$; 24-h post-SIC PD20 $587 \mu \mathrm{g}$ ), but no clinically significant change in FeNO (FeNO pre-SIC $77 \mathrm{ppb}$; post-SIC $70 \mathrm{ppb}$ ). He had negative SICs to the solvent 2,2-aminoethoxyethanol (CAS registry number 929-06-6; occupational asthma hazard index 0.41), $\mathrm{pH}$ stabiliser 2-di-butylaminoethanol (CAS registry number 102-81-8; occupational asthma hazard index 0.95 ) 


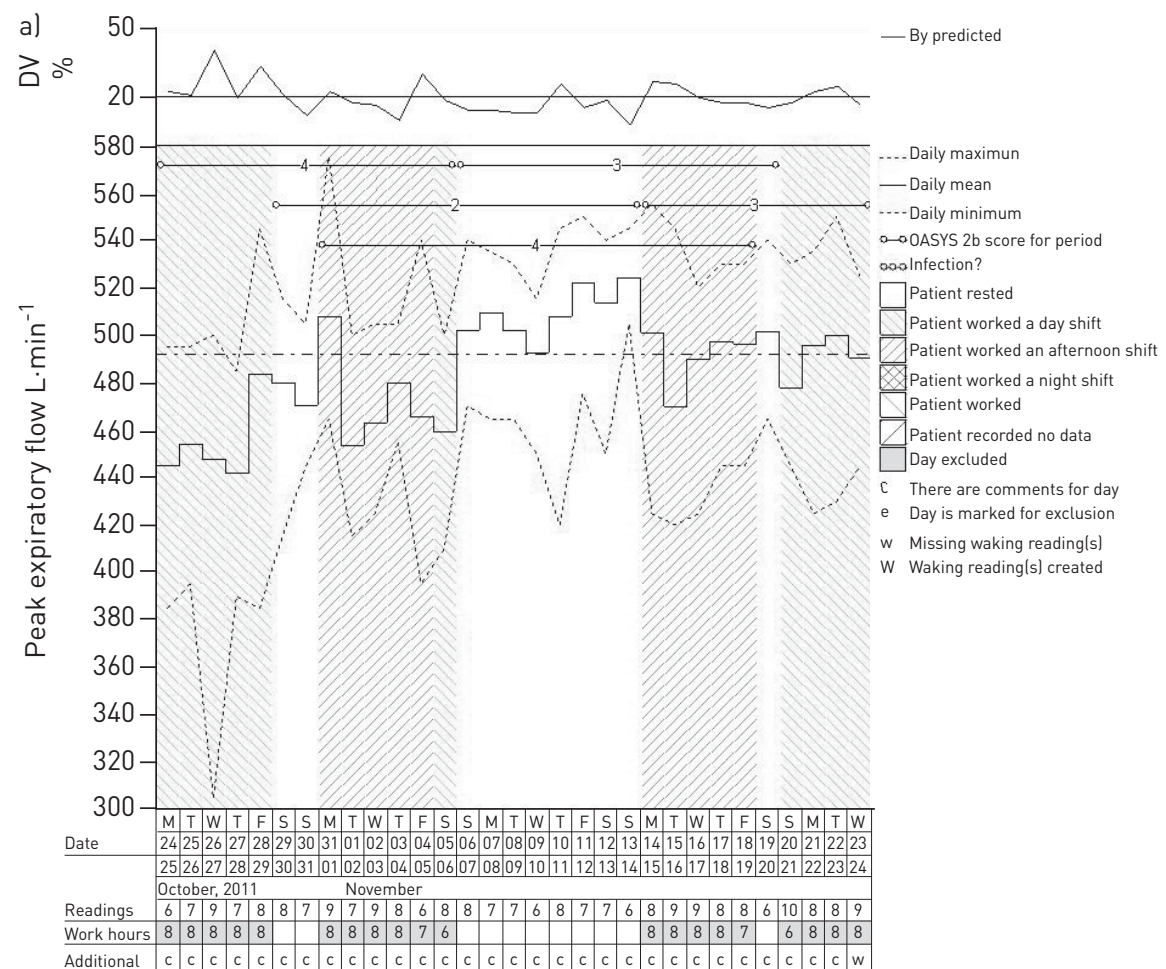

Metalworking fluid

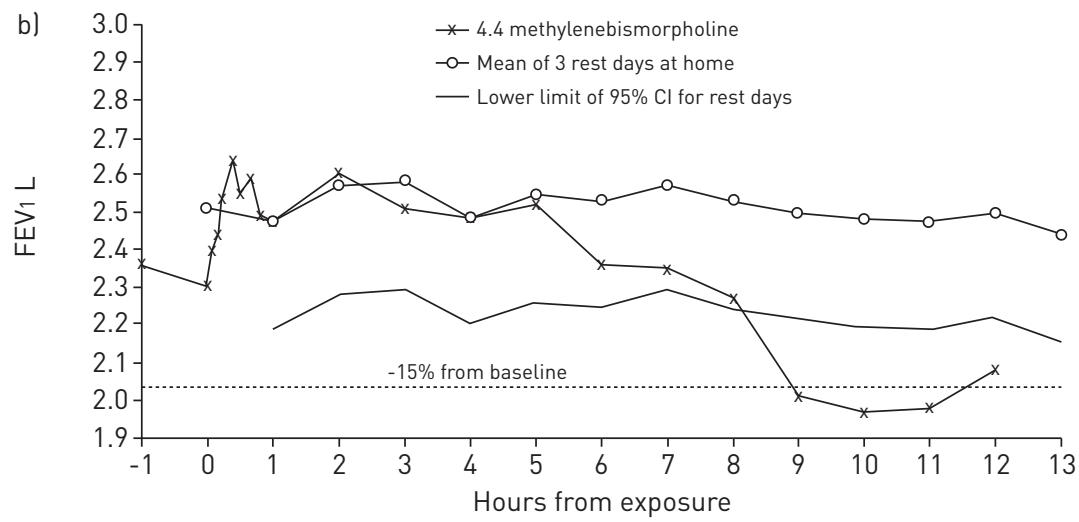

FIGURE 1 a) OASYS analysis of serial peak flow measurements made using a Mini-Wright digital peak flow meter, and showing definite occupational asthma. The top part of the chart shows the diurnal variation (DV) for each day, the middle of the chart shows the maximum, mean and minimum peak flow. The bottom of the record shows the days, dates and number of readings per day for the record. b) Specific inhalational challenge showing a late asthmatic reaction to $0.7 \%$ 4,4-methylene-bismorpholine, with a sustained late fall in forced expiratory volume in $1 \mathrm{~s}$ (FEV1) of $16.5 \%$ at $9 \mathrm{~h}$ post-challenge.

and cobalt chloride $5 \mathrm{mg} \cdot \mathrm{mL}^{-1}$. A suitable unexposed workplace could not be found and 9 months later he remained unemployed with ongoing asthma symptoms. He required treatment with $200 \mu \mathrm{g}$ inhaled beclometasone b.d. with an FEV1 of $2.59 \mathrm{~L}$ (82\% predicted), FVC of $4.45 \mathrm{~L}$ (113\% predicted) and FeNO 56 ppb.

The positive SIC and greater than four-fold increase in NSBR to methacholine supports the diagnosis of occupational asthma from sensitisation due to 4,4-methylene-bismorpholine. GEIER et al. [8] have previously demonstrated dermatological sensitisation to a number of structurally related biocide additives, including $1 \%$ 4,4-methylene-bismorpholine by skin patch testing. However, a number of features need to be accounted for. The baseline FeNO was measured during work exposure and was high, as was the pre-SIC FeNO after 3 weeks away from work, but was lower after 9 months without exposure. These values may have been confounded by atopy and rhinitis $[5,9]$. Some have found a significant increase in FeNO following a late asthmatic reaction; 
however, a significant proportion of low molecular weight occupational asthmagens produce a noneosinophilic asthma variant [10] and, although we did not obtain sputum cell counts, this may explain the lack of FeNO change. All measurements were carried out according to European Respiratory Society/American Thoracic Society guidelines [11] using the NioxMino handheld machine (Aerocrine AB, Solna, Sweden). A $3 \mathrm{~mm}$ SPT to 4,4-methylene-bismorpholine does not provide conclusive evidence of an IgE-mediated mechanism; indeed, the absence of demonstrable specific IgE antibodies in subjects with occupational asthma caused by low molecular weight agents has made many suspect non-IgE mediated mechanisms [12].

Metalworking fluids are used to reduce heat and friction in industrial metalworking operations, and are complex mixtures of oils, emulsifiers, alkaline $\mathrm{pH}$ buffers, biocides and other additives. Once used, metalworking fluids may be contaminated with bacterial and fungal microbes, hydraulic fluid, added biocides, dissolved metals and other manufacturing by-products, all of which are potential sensitisers for occupational asthma, as well as causes of extrinsic allergic alveolitis, humidifier fever and occupational bronchitis [13, 14]. SIC testing to metalworking fluids has been undertaken safely, though positive tests are much more common to used metalworking fluids than to clean metalworking fluids [15, 16]. 4,4-methylene-bismorpholine has a high asthma hazard index (maximum 1.0) using the Manchester Occupational Asthma Hazard Programme, which has a high sensitivity in identifying novel asthmagens [17]. clean metalworking fluid http://ow.ly/nuttg

Gareth I. Walters, Vicky C. Moore, Alastair S. Robertson, Emmet E. McGrath, Edward Parkes and P. Sherwood Burge Occupational Lung Disease Unit, Birmingham Chest Clinic, Birmingham, UK.

Correspondence: G.I. Walters, Occupational Lung Disease Unit, Birmingham Chest Clinic, Great Charles Street, Birmingham, B3 3HX, UK. E-mail: gaxwalters@hotmail.com

Received: Feb 272013 | Accepted: June 192013

Conflict of interest: Disclosures can be found alongside the online version of this article at www.erj.ersjournals.com

\section{References}

1 Baur X, Sigsgaard T. The new guidelines for management of work-related asthma. Eur Respir J 2012; 39: 518-519.

2 Baur X, Sigsgaard T, Aasen TB, et al. Guidelines for the management of work-related asthma. Eur Respir J 2012; 39: 529-545.

3 Gannon PF, Newton DT, Belcher J, et al. Development of OASYS-2: a system for the analysis of serial measurement of peak expiratory flow in workers with suspected occupational asthma. Thorax 1996; 51: 484-489.

4 Moore VC, Jaakkola MS, Burge CBSG, et al. A new diagnostic score for occupational asthma: the area between the curves (ABC score) of peak expiratory flow on days at and away from work. Chest 2009; 135: 307-314.

5 Dweik RA, Boggs PB, Erzurum SC, et al. An official ATS clinical practice guideline: interpretation of exhaled nitric oxide levels (FeNO) for clinical applications. Am J Respir Crit Care Med 2011; 184: 602-615.

6 See KC, Christiano DC. Normal values and thresholds for the clinical interpretation of exhaled nitric oxide levels in the general U.S. population: results from the National Health and Nutrition Examination Survey 2007-2010. Chest 2013; 143: 107-116.

7 Yan K, Salome C, Woolcock AJ. Rapid method for measurement of bronchial responsiveness. Thorax 1983; 38: 760-765.

8 Geier J, Lessmann H, Becker D, et al. Patch testing with components of water-based metalworking fluids: results of a multicentre study with a second series. Contact Dermatitis 2006; 55: 322-329.

9 Scott M, Razal A, Karmaus W, et al. Influence of atopy and asthma on exhaled nitric oxide in an unselected birth cohort study. Thorax 2010; 65: 258-262.

10 Anees W, Huggins V, Pavord ID, et al. Occupational asthma due to low molecular weight agents: eosinophilic and non-eosinophilic variants. Thorax 2002; 57: 231-236.

11 Task force of the European Respiratory Society (ERS) and American Thoracic Society (ATS). ATS/ERS recommendations for standardized procedures for the online and offline measurement of exhaled lower respiratory nitric oxide and nasal nitric oxide. Am J Respir Crit Care Med 2005; 171: 912-930.

12 Sastre J, Vandenplas O, Park HS. Pathogenesis of occupational asthma. Eur Respir J 2003; 22: 364-373.

13 Robertson W, Robertson A, Burge CBSG, et al. Clinical investigation of an outbreak of alveolitis and asthma in a car engine manufacturing plant. Thorax 2007; 62: 981-990.

14 Zacharisen MC, Kadambi AR, Schlueter DP, et al. The spectrum of respiratory disease associated with exposure to metal working fluids. J Occup Environ Med 1998; 40: 640-647.

15 Hendy MS, Beattie BE, Burge PS. Occupational asthma due to an emulsified oil mist. Br J Industr Med 1985; 42: 51-54.

16 Vellore AD, Moore VC, Robertson AS, et al. Specific bronchial challenge testing to metal working fluid. Eur Respir J 2006; 28: Suppl. 50, 245 s.

17 Jarvis J, Seed MJ, Elton R, et al. Relationship between chemical structure and the occupational asthma hazard of low molecular weight organic compounds. Occup Environ Med 2005; 62: 243-250. 